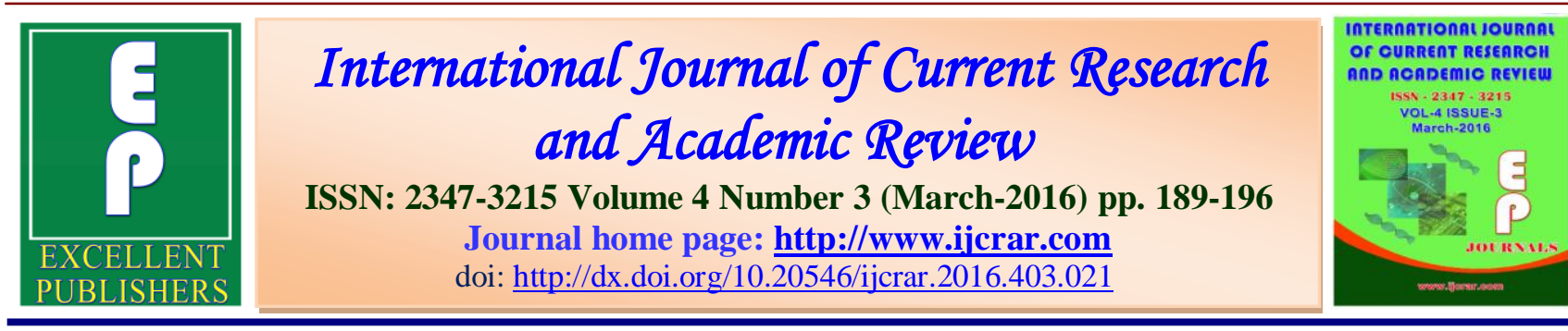

\title{
Oral Self-care Behaviors among Future Dental Professionals in Central India
}

\section{Sudhanshu Saxena $^{1^{*}}$ and N. D. Shashikiran ${ }^{2}$}

${ }^{1}$ Ph.D. Scholar, Pacific Academy of Higher Education and Research University, Udaipur, Rajasthan, India

${ }^{2}$ Dean, Faculty of Dental Sciences, Krishna Institute of Medical Sciences Deemed University, Karad, Maharashtra, India

*Corresponding author

KEYWORDS

Students, Dental, Prevention, Oral,

Self-Care
A B S T R A C T

The need to encourage practice of preventive dentistry in India is critical because the available resources for health care in India as in most developing countries are insufficient to support the traditional curative care of oro-facial diseases. It is therefore important to study how much value dental professionals place on prevention. Such value will be revealed in their oral self-care behaviours. The aim of the present study was to assess oral self-care behaviours among future dental professionals in Central India. A crosssectional questionnaire survey was conducted among dental students of third year, final year and internship of Madhya Pradesh state, India. Questionnaire contains questions regarding personal data, oral hygiene practices, dietary behaviour, tobacco habit and utilization of oral services. Frequency and percentages of responses was calculated. Pearson's chi-square test was used for further data analysis. Cleaning of teeth twice a day was reported by only $29.39 \%$ third year students, $27.99 \%$ fourth year students and $24.85 \%$ interns. Majority of participants were having between meal sugar consumption 'thrice or more' in a day. None of the participants had ever visited a dentist for regular check-up. Oral self-care behaviours of future dental professionals in Central India need to be improved so that they can serve as role model for their patients.

\section{Introduction}

According to World Health Organization oral health implies being free of chronic orofacial pain, oral and pharyngeal (throat) cancer, oral tissue lesions, birth defects such as cleft lip and palate, and other diseases and disorders that affects the oral, dental and craniofacial tissues, collectively known as craniofacial complex (Petersen, 2003). Oral diseases affect a significant proportion of the world's population. The most common oral 
problems, caries and periodontal disease, are bacterial in origin, exacerbated by dietary sugars, ineffective plaque removal, and less than optimal fluoride availability (Blinkhorn, 1998). Also, the interrelationship between oral and general health is proven by evidence (Watt, 2005). This further emphasizes that good oral health is essential for general well-being. Most oral diseases are nevertheless largely preventable. The caries-preventive methods ranked by experts as effective for the caries decline in the industrialised countries are the use of fluoride in various forms, improved oral hygiene, and sensible sugar consumption (Bratthall et al., 1996). Although there has been a marked improvement in dental health in many developed countries (Wagle et al., 2014), the prevalence of oral diseases is increasing in many low and middle income countries (Petersen and Kwan, 2010). Changes in dietary patterns, increased consumption of sweetened drinks, level of education (Knevel, 2005), poor oral hygiene, smoking, and alcohol consumption are the major contributors to the increased prevalence of oral diseases (World Health Organization, 2016).

At a society level, treating dental diseases is very costly for health care systems. For lowand middle-income countries, meeting the current need for treatment would exceed most health-care budgets, leaving prevention as the only viable option (World Health Organization, 2015).

In India, number of dental schools grew significantly in the past three decades (Elangovan et al., 2010). This data is providing a very positive indication as far as availability of the dental workforce is concerned. The need to encourage the practice of preventive dental care in India is critical because the available resources for health care in India as in most developing countries are insufficient to support the traditional curative care of oro-facial diseases. Changing socio-economic circumstances and the needs and demands of the Indian population require current and future dental professionals to broaden their efforts towards a community level, contrasting with their previous practice which had focused only at an individual level. Dental professionals are educated to promote better oral hygiene in the society. It is therefore important to study how much value dental professionals place on prevention. Such value will be revealed in their oral self-care behaviours also. Hence, the aim of the present study was to assess oral self-care behaviours among future dental professionals in Central India.

\section{Materials and Methods}

Study Population: The study population comprised of future dental professionals of Madhya Pradesh state, India. The future professionals were represented by dental students in their clinical years (third year, final year and internship) at the dental colleges of Madhya Pradesh state, India in 2014. There are total 15 dental colleges in Madhya Pradesh with one government and 14 private dental colleges. Among them 06 are in Bhopal, 05 in Indore, 02 in Gwalior, 01 each in Jabalpur and Burhanpur cities. Total intake per year is of 1360 undergraduate and 229 postgraduate students (Dental Council of India, 2016).

\section{Pilot Study}

The English version of the questionnaire was first pre-tested among ten dental students of third year, final year and internship of Hitkarini Dental College and Hospital, Jabalpur, Madhya Pradesh state, India and People's College of Dental 
Sciences and Research Centre, Bhopal, Madhya Pradesh state, India in December 2013. Necessary changes were made to prepare revised and final version of the questionnaire. Dental students among whom pilot testing was performed were excluded from the final data collection.

\section{Sampling Technique}

Cluster random sampling technique was followed for data collection.

Sample size: Based on the results of the pilot study, sample size calculated was 291 dental students per year. It was increased by $15 \%$ to compensate for non-response or incomplete responses of participants. Hence the final sample size for the present study was 335 dental students per year.

\section{Study Design}

Cross-sectional design was used for data collection.

\section{Questionnaire}

Questionnaire had two parts. First part of questionnaire was designed to collect personal data, inquiring about year of study, age and gender. Second part comprises questions on oral hygiene practices, dietary behavior, tobacco habit and utilization of oral services.

\section{Data Collection}

During April-May 2014, the final version of the questionnaire was delivered by the investigator to all dental students of third year, final year and internship at People's Dental Academy, Bhopal, Madhya Pradesh state, India, Mansarovar Dental College, Hospital and Research Centre, Bhopal, Madhya Pradesh state, India, Rishiraj
College of Dental Sciences and Research Centre, Bhopal, Madhya Pradesh state, India, Sri Aurobindo College of Dentistry, Indore, Madhya Pradesh state, India and Hitkarini Dental College and Hospital, Jabalpur, Madhya Pradesh state, India in their classrooms. Students absent on the particular day of data collection were contacted on next day. If they were absent on next day also, no further attempt was made.

\section{Ethical Clearance}

Ethical clearance for the study was obtained from ethical committee of the institution.

\section{Statistical Analysis}

Frequency and percentages of responses was calculated. Pearson's chi-square test was used for further data analysis. $P$ values $<0.05$ were considered statistically significant. Data analyses were performed using SPSS v21.0 for windows.

\section{Results and Discussion}

There were more females than males in all the study years (Figure 1). Mean (SD) age for third year, final year and interns were $21.86(0.82)$ years, $22.74(0.88)$ years and 23.78 (0.88) years, respectively (Figure 2).

When participants were asked about awareness regarding fluoride in toothpaste, $70.30 \%$ third year students, $87.76 \%$ fourth year students and $97.85 \%$ interns said that they were aware about it. Chi-square test showed significant difference between different study years $\left(\chi^{2}=101.722\right.$, $\mathrm{df}=2, \mathrm{P}$ $<0.001)$. However no significant difference was observed for use of fluoride containing toothpaste $\left(\chi^{2}=0.055\right.$, df $\left.=2, \mathrm{P}>0.05\right)$. Cleaning of teeth twice a day was reported by only $29.39 \%$ third year students, $27.99 \%$ 
fourth year students and $24.85 \%$ interns. There was no significant different between different study years $\left(\chi^{2}=1.786, \mathrm{df}=2, \mathrm{P}\right.$ $>0.05$ ) (Table 1).

Between meal sugar consumption 'thrice or more' in a day was reported by $55.15 \%$ third year students, $59.77 \%$ fourth year students and $66.87 \%$ interns. Chi-square test showed significant difference between different study years $(\chi 2=10.470, \mathrm{df}=4, \mathrm{P}<0.05)$. Practice of tobacco was reported by only $7.88 \%$ third year students, $8.16 \%$ fourth year students and $7.67 \%$ interns. There was no significant different between different study years $\left(\chi^{2}=0.057, \mathrm{df}=2, \mathrm{P}>0.05\right)($ Table 2$)$.

Participants were asked whether they had ever visited a dentist. Nearly $50 \%$ of third year students, $46.06 \%$ of fourth year students and $32.51 \%$ of interns had never visited a dentist. More visits were reported by interns. Chi-square test showed significant difference between different study years $\left(\chi^{2}=25.921\right.$, df $\left.=6, \mathrm{P}<0.001\right)$. However none of the participants have ever visited for regular dental check-up (Table 3).

Good oral health is essential for individual's well-being and is vital to good general health (Petersen, 2003). Dental education plays a central role in creating dental workforce equipped with appropriate attitudes, understanding and competencies in preventive dentistry (Brown et al., 2002). Present study was designed to assess oral self-care behaviours among future dental professionals in Madhya Pradesh state of Central India.

In present study most of the participants were aware regarding fluoridated dentifrices and were using the same 'always or almost always'. In a study among Nigerian dental students more than $95 \%$ reported use of use of fluoride containing toothpaste (Folayan et al., 2013). Majority of dental students in present study were brushing once in a day. In earlier studies, brushing more than once in a day was reported by $47.5 \%$ dental students in Nigeria, $78 \%$ in France, $57 \%$ in Iran, $80 \%$ in Australia (Folayan et al., 2013) and $81.0 \%$ in Mongolia (Tseveenjav, 2004). Al-Batayneh et al. (2014) in a study among diverse university students found that $57.1 \%$ of dental students brush three times in a day.

Diet rich in sugar is one of the key factors in etiology of dental caries (Lingstrom et al., 2003). Despite of this fact majority of participants in present study were having between meal sugar consumption 'thrice or more' in a day. In another studies, $56.5 \%$ Nigerian dental students (Folayan et al., 2013) and $60 \%$ of Iranian dental students (Ghasemi et al., 2007) have preferred in between meal sugar containing food.

Tobacco habit was reported by nearly eight percent of dental students in present investigation. Nearly $6.2 \%$ of Nigerian dental students have ever smoked in their life time (Folayan et al., 2013).

In the present study participants were asked whether they had ever visited a dentist. Nearly $50 \%$ of third year students, $46.06 \%$ of fourth year students and $32.51 \%$ of interns had never visited a dentist. Also, none of the participants have ever visited for regular dental check-up. In another research, nearly $6.8 \%$ Nigerian dental students (Folayan et al., 2013) have never visited a dentist. In a study by Al-Batayneh et al. (2014) nearly 48\% reported "dental pain or bleeding gums" as a predominant reason for visiting dentist.

In an investigation by Halawany et al. (2015) among dental students of four Asian countries, $63.9 \%$ responded brushing twice daily. In total, $70 \%$ perceived their dental health as good and $72.6 \%$ visited dentist only at the time of dental problem. In the 
Int.J.Curr.Res.Aca.Rev.2016; 4(3): 189-196

same study $77.6 \%$ Indian students reported brushing twice in a day. Visit to dentist only during dental problems was reported by $79.4 \%$ Indian students.

Figure.1 Gender Distribution of Study Subjects

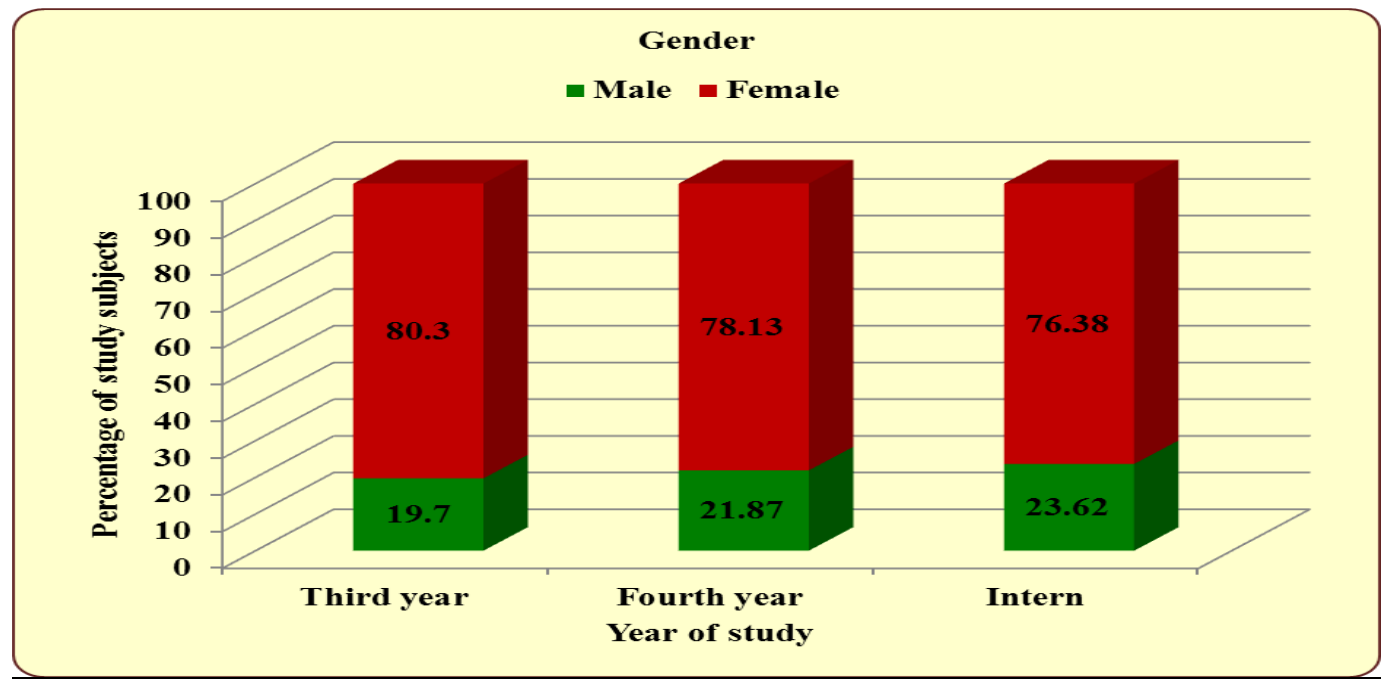

Figure.2 Mean and Standard Deviation (SD) of Age of Study Subjects According to Year of Study

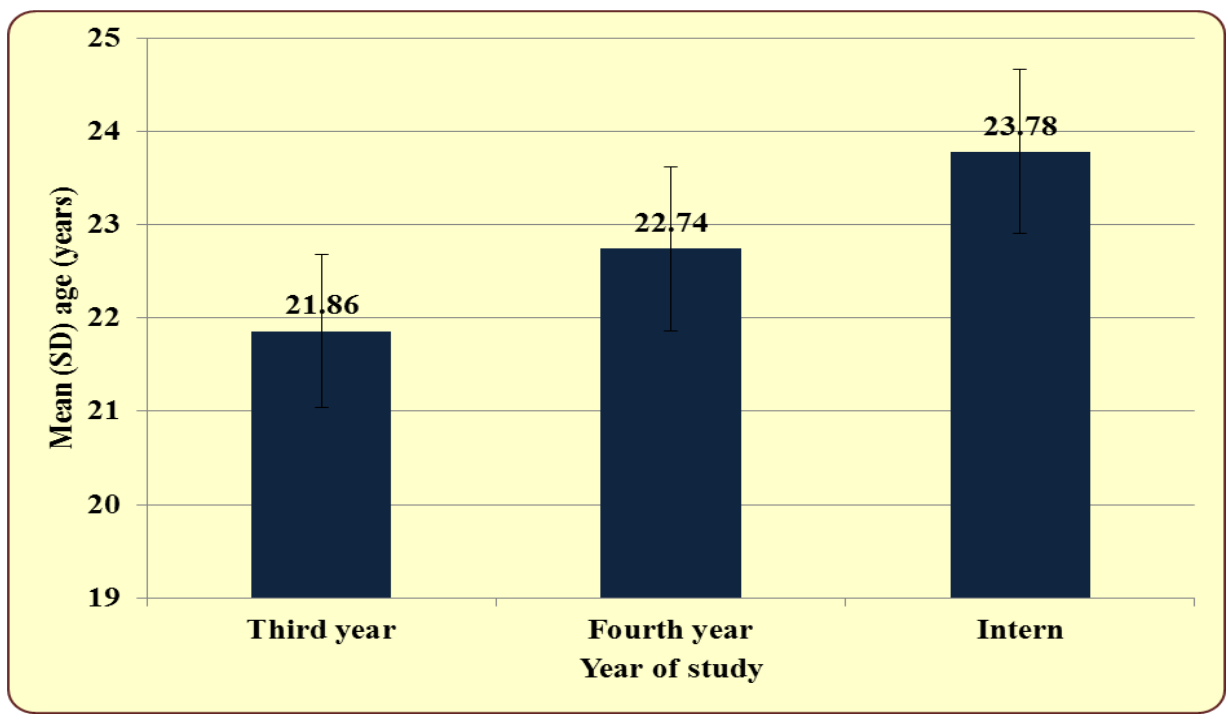


Int.J.Curr.Res.Aca.Rev.2016; 4(3): 189-196

Table.1 Oral Hygiene Practices of Dental Students

\begin{tabular}{|c|c|c|c|c|c|}
\hline \multirow[b]{2}{*}{$\begin{array}{c}\text { Oral hygiene } \\
\text { practices }\end{array}$} & \multirow[b]{2}{*}{ Responses } & \multicolumn{3}{|c|}{ Year of study } & \multirow[b]{2}{*}{ Chi-square test } \\
\hline & & $\begin{array}{c}\text { Third year } \\
\mathrm{n}(\%)\end{array}$ & $\begin{array}{c}\text { Fourth year } \\
\mathrm{n}(\%)\end{array}$ & $\begin{array}{c}\text { Intern } \\
\mathrm{n}(\%)\end{array}$ & \\
\hline \multirow{2}{*}{$\begin{array}{l}\text { Awareness } \\
\text { regarding } \\
\text { fluoride in } \\
\text { toothpaste }\end{array}$} & Yes & $232(70.30)$ & $301(87.76)$ & $319(97.85)$ & \multirow{2}{*}{$\begin{array}{c}\chi^{2}=101.722 \\
\mathrm{df}=2 \\
\mathrm{P}=0.000(<0.001) \\
\text { Sig. diff. }\end{array}$} \\
\hline & Do not know & $98(29.70)$ & $42(12.24)$ & $07(2.15)$ & \\
\hline \multirow{4}{*}{$\begin{array}{l}\text { Use of fluoride } \\
\text { containing } \\
\text { toothpaste* }\end{array}$} & Not at all & $00(0.00)$ & $00(0.00)$ & $00(0.00)$ & \multirow{4}{*}{$\begin{array}{c}\chi^{2}=0.055 \\
\mathrm{df}=2 \\
\mathrm{P}=0.973(>0.05) \\
\text { Not sig. }\end{array}$} \\
\hline & Seldom & $47(20.26)$ & $60(19.93)$ & 66 (20.69) & \\
\hline & Quite often & $00(0.00)$ & $00(0.00)$ & $00(0.00)$ & \\
\hline & $\begin{array}{l}\text { Always or } \\
\text { almost } \\
\text { always }\end{array}$ & 185 (79.74) & $241(80.07)$ & $253(79.31)$ & \\
\hline \multirow{2}{*}{$\begin{array}{l}\text { Frequency of } \\
\text { tooth cleaning\# }\end{array}$} & Once & $233(70.61)$ & $247(72.01)$ & $245(75.15)$ & \multirow{2}{*}{$\begin{array}{c}\chi^{2}=1.786 \\
\mathrm{df}=2 \\
\mathrm{P}=0.409(>0.05) \\
\text { Not sig. }\end{array}$} \\
\hline & Twice & 97 (29.39) & $96(27.99)$ & $81(24.85)$ & \\
\hline
\end{tabular}

* Applicable for students who had knowledge regarding fluoride in toothpaste

\# One time cleaners reported it in the morning immediately after waking up. Twice cleaners reported it in the morning immediately after waking up and in the night before going to bed

Table.2 Dietary Behaviour and Tobacco Habit of Dental Students

\begin{tabular}{|c|c|c|c|c|c|}
\hline \multirow{2}{*}{$\begin{array}{c}\text { Dietary } \\
\text { behaviour and } \\
\text { tobacco habit }\end{array}$} & \multirow[b]{2}{*}{ Responses } & \multicolumn{3}{|c|}{ Year of study } & \multirow[b]{2}{*}{ Chi-square test } \\
\hline & & $\begin{array}{c}\text { Third year } \mathrm{n} \\
(\%)\end{array}$ & $\begin{array}{c}\text { Fourth year } \\
\mathrm{n}(\%)\end{array}$ & $\begin{array}{c}\text { Intern } \\
\mathrm{n}(\%)\end{array}$ & \\
\hline \multirow{3}{*}{$\begin{array}{l}\text { Frequency of } \\
\text { between meal } \\
\text { sugar } \\
\text { consumption }\end{array}$} & Once & $51(15.45)$ & $41(11.95)$ & $33(10.12)$ & \multirow{3}{*}{$\begin{array}{c}\chi^{2}=10.470 \\
\mathrm{df}=4 \\
\mathrm{P}=0.033(<0.05) \\
\text { Sig. diff. }\end{array}$} \\
\hline & Twice & $97(29.39)$ & $97(28.28)$ & $75(23.01)$ & \\
\hline & $\begin{array}{l}\text { Thrice or } \\
\text { more }\end{array}$ & $182(55.15)$ & 205 (59.77) & $218(66.87)$ & \\
\hline \multirow{2}{*}{ Tobacco habit } & Yes & $26(7.88)$ & $28(8.16)$ & $25(7.67)$ & \multirow{2}{*}{$\begin{array}{c}\chi^{2}=0.057 \\
\mathrm{df}=2 \\
\mathrm{P}=0.972(>0.05) \\
\text { Not sig. }\end{array}$} \\
\hline & No & 304 (92.12) & $315(91.84)$ & $301(92.33)$ & \\
\hline
\end{tabular}

Table.3 Utilization of Oral Services by Dental Students

\begin{tabular}{|c|c|c|c|c|c|}
\hline \multirow{2}{*}{$\begin{array}{l}\text { Utilization of } \\
\text { oral services }\end{array}$} & \multirow[b]{2}{*}{ Responses } & \multicolumn{3}{|c|}{ Year of study } & \multirow[b]{2}{*}{ Chi-square test } \\
\hline & & $\begin{array}{c}\text { Third year } \mathrm{n} \\
(\%)\end{array}$ & $\begin{array}{c}\text { Fourth year } \\
\mathrm{n}(\%)\end{array}$ & $\begin{array}{c}\text { Intern } \\
\mathrm{n}(\%) \\
\end{array}$ & \\
\hline \multirow{4}{*}{$\begin{array}{l}\text { Duration since } \\
\text { last dental visit }\end{array}$} & $\leq 6$ months & $33(10.00)$ & $30(8.75)$ & $41(12.58)$ & \multirow{4}{*}{$\begin{array}{c}\chi^{2}=25.921 \\
\mathrm{df}=6 \\
\mathrm{P}=0.000(<0.001) \\
\text { Sig. diff. }\end{array}$} \\
\hline & $\begin{array}{l}>6 \text { months to } \leq 1 \\
\text { year }\end{array}$ & $37(11.21)$ & 41 (11.95) & $36(11.04)$ & \\
\hline & $>1$ year & $96(29.09)$ & $114(33.24)$ & $143(43.87)$ & \\
\hline & Never & $164(49.70)$ & $158(46.06)$ & $106(32.51)$ & \\
\hline \multirow{2}{*}{$\begin{array}{l}\text { Reason for } \\
\text { visit* }\end{array}$} & Oral problems & $166(100.00)$ & $185(100.00)$ & $220(100.00)$ & \multirow[b]{2}{*}{ Test not applicable } \\
\hline & $\begin{array}{l}\text { Regular dental } \\
\text { check-up }\end{array}$ & $00(0.00)$ & $00(0.00)$ & $00(0.00)$ & \\
\hline
\end{tabular}

\footnotetext{
* Applicable for students who ever had dental visit
} 
Similar to present investigation, in a study by Hashim and Ibrahim (2013), better oral health attitudes, behaviour, especially towards gingival health, oral hygiene practice, tooth brushing and visiting the dentist were reported by the dental students in Ajman, United Arab Emirates as they progressed in their education from first year to fifth year. This could be due to contact of students with patients in clinical experience and progress in dental education make them more aware and attentive to adopt better oral heath behaviour (Hashim and Ibrahim, 2013). Though, Dagli et al. (2008) have reported no effects of study year on oral health behaviour.

Self-administered questionnaires were used as data collection tool in the present study. This tool has advantage of being free of interviewer effects. However, there is a chance of bias from the participants concerning the degree of honesty of their answers.

In conclusion, oral self-care behaviours of future dental professionals in Central India need to be improved so that they can serve as role model for their patients. More emphasis on preventive approaches in dental education is therefore, needed.

\section{References}

Al-Batayneh, O.B., Owais, A.I. and Khader, Y.S. 2014. Oral health knowledge and practices among diverse university students with access to free dental care: A cross-sectional study. Open J Stomatol. 4(3): 135142.

Blinkhorn, A.S. 1998. Dental health education: what lessons have we ignored? Br Dent J. 184(2): 58-59.

Bratthall, D., Hansel-Petersson, G. and Sundberg, H. 1996. Reasons for the caries decline: what do the experts believe? Eur J Oral Sci. 104(4): 416432.

Brown, G., Manogue, M. and Rohlin, M. 2002. Assessing attitudes in dental education: is it worthwhile? Br Dent J. 193(12): 703-707.

Dagli, R.J., Tadakamadla, S., Dhanni, C., Duraiswamy, P. and Kulkarni, S. 2008. Self reported dental health attitude and behavior of dental students in India. J Oral Sci. 50(3): 267-272.

Dental Council of India [Internet]. [cited 2016 Feb 10]. Available from: http://www.dciindia.org.in

Elangovan, S., Allareddy, V., Singh, F., Taneja, P. and Karimbux, N. 2010. Indian dental education in the new millennium: challenges and opportunities. J Dent Educ. 74(9): 1011-1016.

Folayan, M.O., Khami, M.R., Folaranmi, N., Popoola, B.O., Sofola, O.O., Ligali, T.O., et al. 2013. Determinants of preventive oral health behaviour among senior dental students in Nigeria. BMC Oral Health. 13: 28.

Ghasemi, H., Murtomaa, H., Torabzadeh, H. and Vehkalahti, M.M. 2007. Knowledge of and Attitudes towards Preventive Dental Care among Iranian Dentists. Eur J Dent. 1(4): 222-229.

Halawany, H.S., Abraham, N.B., Jacob, V. and Al-Maflehi, N. 2015. The perceived concepts of oral health attitudes and behaviors of dental students from four Asian countries. Saudi J Dent Res. 6: 79-85.

Hashim, R. and Ibrahim, M. 2013. Oral health attitudes and behavior among dental students in Ajman, United Arab Emirates. J Int Dent Med Res. 6(2): 84-87.

Knevel, R.J.M. 2005. Dental hygienists on 
top of the world: supporting oral health education in Nepal. Int $\mathbf{J}$ Dent Hyg. 3(4): 205-212.

Lingstrom, P., Holm, A.K., Mejare, I., Twetman, S., Soder, B., Norlund, A., et al. 2003. Dietary factors in the prevention of dental caries: a systematic review. Acta Odontol Scand. 61(6): 331-340.

Petersen, P.E. 2003. The World Oral Health Report 2003: continuous improvement of oral health in the 21 st century-the approach of the WHO Global Oral Health Programme. Community Dent Oral Epidemiol. 31 Suppl 1: 3-23.

Petersen, P.E. and Kwan, S. 2010. The 7th WHO Global Conference on Health Promotion - towards integration of oral health (Nairobi, Kenya 2009). Community Dent Health. 27 Suppl 1: 129-136.
Tseveenjav, B. 2004. Preventive Dentistry in Mongolia. Dissertation: University of Helsinki.

Wagle, M., Trovik, T.A., Basnet, P. and Acharya, G. 2014. Do dentists have better oral health compared to general population: a study on oral health status and oral health behavior in Kathmandu, Nepal. BMC Oral Health. 14: 23.

Watt, R.G. 2005. Strategies and approaches in oral disease prevention and health promotion. Bull World Health Organ. 83(9): 711-718.

World Health Organization. 2015. Prevention is better than treatment. Bull World Health Organ. 93(9): 594-595.

World Health Organization: Oral health.

\section{How to cite this article:}

Sudhanshu Saxena and Shashikiran, N.D. 2016. Oral Self-care Behaviors among Future Dental Professionals in Central India. Int.J.Curr.Res.Aca.Rev.4(3): 189-196. doi: http://dx.doi.org/10.20546/ijcrar.2016.403.021 